\title{
Kualitas pelayanan kesehatan rawat jalan dengan tingkat kepatuhan minum obat penderita tuberkulosis paru
}

\author{
Ahmad Gunawan ${ }^{1}$, Muhammad Arifki Zainaro ${ }^{2 \star}$ \\ 1UPT Puskesmas Rawat Inap Sragi Kabupaten Lampung Selatan. *Email: ahmadgunawan1965@gmail.com \\ 2Program Studi Diploma III Keperawatan Malahayati Bandar Lampung. Email: m.arifkiz@yahoo.com
}

\section{Abstract \\ Adherence to anti-tuberculosis treatment and quality of outpatient health services}

Background: The were 23 lung tuberculosis patients registered at Sragi Health Center. Actually, the Case Detection Rate of Tuberculosis in Lampung Selatan Regency was $60 \%$, below the $70 \%$ national target. How ever, specifically in some health centers in the regency, there were some health centers which Case Detection Rate (CDR) is higher than national achievement like Bakauheni Health Center (116\%) while the lowest CDR found at Bumidaya Health Center. In this study, Sragi Health Center obtained 41\% placing the fourth lowest achievement. On the following year, 2017, Sragi Health Center's lung tuberculosis patients increased into 38 resulting the second lowest CDR achieve in Lampung Selatan regency.

Purpose: To identify the correlation between empathy of health practitioner and the adherence to anti-tuberculosis treatment.

Methods: A quantitative study with cross sectional research approach, by total sampling and population was 49 patients with lung tuberculosis. Study was done on 23 March to 25 July 2019 at Sragi Health Center (Puskesmas). The variables are quality of outpatient health services in domain an empathy and the adherence to anti-tuberculosis treatment.

Result: Finding that there were of 29 patients $(59,2 \%)$ acknowledging the health practitioners having good empathy while the other twenty $(40,8 \%)$ stating the health practitioners exhibiting poor empathy. There was a correlation between empathy of health practitioners and the adherence of taking medicine on lung tuberculosis patients ( $p$ value $=$ 0,009 and OR 6,545).

Conclusion: There was a correlation between empathy of health practitioners and the adherence to anti-tuberculosis treatment. The health practitioners especially the nurses should show their empathy to the patients in order to build trust to healthcare.

\section{Keywords: Adherence; Anti-Tuberculosis Treatment; Quality; Outpatient Health Services; Empathy}

Pendahuluan: Puskesmas Sragi sebanyak 23 penderita. CDR (Case Detection Rate) Kabupaten Lampung Selatan tahun 2016 sebesar 60\% masih dibawah target nasional sebesar 70\%, tetapi bila ditilik terdapat beberapa Puskesmas yang mempunyai capaian nilai CDR diatas nasional seperti Puskesmas RI Bakauheni $(116 \%)$, sedangkan Puskesmas dengan CDR terendah adalah RI Bumidaya (30\%) dan Puskesmas Sragi sebesar $41 \%$ merupakan urutan yang ke empat terendah. Tahun 2017 Puskesmas Sragi kembali mengalami peningkatan penderita TB paru menjadi sebanyak 38 orang dengan CDR urutan kedua terendah di Kabupaten Lampung Selatan.

Tujuan: Diketahui empati petugas kesehatan dengan kepatuhan minum obat penderita tuberculosis paru.

Metode: Penelitian kuantitatif, jenis penelitian crossectional. Populasi penelitian seluruh penderita TB paru, jumlah sampel 49 orang, pengambilan sampel secara total sampling dilakukan di UPT Puskesmas Rawat Inap Sragi Kabupaten Lampung Selatan, tanggal 23 Maret - 25 Juli 2019. Variabel penelitian empatidan kepatuhan minum obat penderita tuberculosis paru. Analisis data secara univariat dan bivariat (chi square).

Hasil: Diketahui sebanyak 29 (59,2\%) memiliki empati baik dan sebanyak $20(40,8 \%)$ memiliki rasa empati yang buruk. Ada hubungan antara empati petugas kesehatan terhadap kepatuhan minum obat tuberculosis paru(pvalue $=0,009$ dan OR 6,545).

Simpulan: Ada hubungan antara empati petugas kesehatan terhadap kepatuhan minum obat tuberculosis paru. Saran: Perawat dan petugas kesehatan supaya bersikap empati agar pasien lebih nyaman dan merasa dilindungi dan dibantu sehingga dapat menciptakan kondisi yang terapeutik. Pasien akan selalu kontrol dan patuh dalam minum obat tuberculosis paru hingga dosisnya sesuai anjuran yang ditetapkan.

Kata kunci: Tuberkulosis Paru; Empati; Kepatuhan; Petugas Kesehatan 


\section{PENDAHULUAN}

Tuberkulosis sampai saat ini masih menjadi masalah kesehatan masyarakat di dunia, terutama di negara-negara berkembang termasuk Indonesia. Penyakit ini merupakan ancaman besar bagi pembangunan sumber daya manusia sehingga perlu mendapatkan perhatian yang lebih serius dari semua pihak. Tuberculosis (TB) adalah suatu penyakit infeksi menular yang disebabkan oleh microbacterium tuberculosis yang dapat menyerang berbagai organ khususnya paru-paru, jika tidak diobati atau pengobatannya tidak tuntas maka dapat menimbulkan komplikasi hingga dapat menyebabkan kematian (Kementerian Kesehatan Republik Indonesia, 2016). TB merupakan penyakit yang menjadi perhatian global. Sesuai dengan tujuan pembangunan berkelanjutan 2030, World Health Organization (WHO) menargetkan untuk menurunkan kematian akibat tuberkulosis sebesar $90 \%$ dan menurunkan insiden sebesar $80 \%$ pada tahun 2030 (Kementerian Kesehatan Republik Indonesia, 2017).

Pada tahun 2016, kasus baru TB dilaporkan sebanyak 6,3 juta (naik dari 6,1 juta pada tahun 2015). Data hasil pengobatan terbaru menunjukkan tingkat keberhasilan pengobatan global sebesar 83\%, Sebanyak 129.689 orang memulai pengobatan untuk TB yang resistan terhadap obat, namun keberhasilan pengobatan tetap rendah, yaitu $54 \%$ di seluruh dunia. Indonesia merupakan negara dengan jumlah kasus baru terbanyak kedua di dunia setelah India diikuti China, Nigeria, Pakistan dan Afrika Selatan dengan kasus baru sebesar 60\% (World Health Organization, 2017; Kementerian Kesehatan Republik Indonesia, 2017).

Berdasarkan Pedoman Nasional Penanggulangan Tuberkulosis di Indonesia, target angka kesembuhan yang harus dicapai adalah $>85 \%$ dengan merekomendasikan DOTS (Directly Observed Treatment Short course). Pada tahun 2013, angka kesembuhan menurun menjadi $60 \%$. Bahkan, angka kesembuhan bagi penderita $\mathrm{Tb}$ masih rendah yaitu 47\%, pada tahun 2016 angka kesembuhan mencapai $85 \%$ tetapi perlu diperhatikan beberapa pasien dengan hasil pengobatan lengkap, meninggal, gagal, putus berobat dan tidak terevaluasi (Kementerian Kesehatan Republik Indonesia, 2016).

Jumlah BTA + sebanyak 5.612 penderita dengan Cure rate $75,69 \%$ dan sembuh sebesar
93\%. Angka Keberhasilan Pengobatan di Propinsi Lampung tahun 2016 sudah mencapai target yaitu 92,6 \%. Dengan cakupan tertinggi di Kabupaten Lampung Utara sebesar $100 \%$ dan terendah di Kabupaten Lampung Barat sebesar 24.36\% sedangkan kabupaten Lampung Selatan sebesar 33.19\% kedua terendah di Provinsi Lampung (Dinas Kesehatan Provinsi Lampung, 2017).

Pada tahun 2016 jumlah seluruh kasus TB sebanyak 1.272 kasus meningkat dari tahun sebelumnya 1.166 kasus. Angka penemuan kasus TB BTA positif tahun 2016 sebesar 947 kasus $(60 \%)$ meningkat dari tahun sebelumnya sebesar 919 kasus (59\%). Berdasarkan jenis kelamin penemuan kasus TB paru sebanyak $70 \%$ laki-laki dan $30 \%$ perempuan. Penyebaran kasus baru BTA (+) di Kabupaten Lampung Selatan pada tahun 2016 yang tertinggi berada di wilayah kerja Puskesmas Tanjung Bintang sebanyak 66 kasus dan yang terendah di Puskesmas Bumidaya sebanyak 11 kasus, sedangkan pada tahun 2015 yang tertinggi di Puskesmas Natar sebanyak 78 kasus dan yang terendah di Puskesmas Sukadamai sebanyak 14 kasus. Sedangkan Puskesmas Sragi sebanyak 23 penderita. CDR (Case Detection Rate) Kabupaten Lampung Selatan tahun 2016 sebesar 60\% masih dibawah target nasional sebesar $70 \%$, tetapi bila ditilik terdapat beberapa Puskesmas yang mempunyai capaian nilai CDR diatas nasional seperti Puskesmas RI Bakauheni (116\%), sedangkan Puskesmas dengan CDR terendah adalah RI Bumidaya (30\%) dan Puskesmas Sragi sebesar $41 \%$ merupakan urutan yang ke empat terendah Tahun 2017 Puskesmas Sragi kembali mengalami peningkatan penderita TB paru menjadi sebanyak 38 orang dengan CDR urutan kedua terendah di Kabupaten Lampung Selatan (Dinas Kesehatan Lampung Selatan, 2017).

Angka kesembuhan pasien Tuberkulosis Paru berkaitan dengan umur, jenis kelamin, keteraturan berobat, kepatuhan memeriksakan dahak, dukungan PMO, serta jarak tempat tinggal dengan puskesmas Finn, Martin, Rugo, Jones, Gelmon, \& Gauthier, 2016. Keberhasilan pengobatan TB paru pada pasien juga membutuhkan dukungan dan bantuan dari orang lain di sekitarnya. Dukungan informasi sangat diperlukan pasien untuk mendapatkan petunjuk informasi yang dibutuhkan. Motivasi pasien untuk sembuh dipengaruhi faktor lingkungan pelayanan kesehatan, dokter, perawat

Muhammad Arifki Zainaro ${ }^{1}$ Program Studi Diploma III Keperawatan Malahayati Bandar Lampung.

Email: m.arifkiz@yahoo.com

Ahmad Gunawan²* UPT Puskesmas Rawat Inap Sragi Kabupaten Lampung Selatan.

*Email: ahmadgunawan1965@gmail.com 
dan tenaga kesehatan lain serta dukungan dari keluarga (Subhakti, 2014). Penelitian Sebelumya juga telah membuktikan bahwa dimensi kualitas pelayanan secara individual dan bersama-sama mempunyai pengaruh yang signifikan terhadap kepuasan pasien rawat jalan, Selain itu, hasil penelitian lain juga menyimpulkan bahwa kualitas pelayanan dan kepuasan berpengaruh positif terhadap loyalitas pasien rawat jalan dan rawat inap (Nursini, 2010; Puti, 2013; Pribadi, 2017).

Sebagai salah satu pemberi pelayanan kesehatan maka UPT Puskesmas Rawat Inap Sragi di tuntut untuk memberikan pelayanan yang memuaskan kepada pasien dengan peningkatan mutu. Peningkatan kualitas pelayanan merupakan salah satu isu yang sangat krusial dalam manajemen, baik dalam sektor pemerintah maupun sektor swasta. Hal ini terjadi karena di satu sisi tuntutan masyarakat terhadap perbaikan kualitas pelayanan dari tahun ke tahun menjadi semakin besar, Kualitas pelayanan kesehatan menunjukkan pada tingkat kesempurnaan pelayanan kesehatan pada diri setiap pasien (Pohan, 2017).

Kualitas pelayanan (service quality) dapat diketahui dengan cara membandingkan persepsi para konsumen atas pelayanan yang nyata-nyata mereka terima / peroleh dengan pelayanan yang sesungguhnya mereka harapkan / inginkan terhadap atribut-atribut pelayanan (Tjiptono, 2015). Lima aspek komponen mutu pelayanan dikenal dengan nama Servqual (Service Quality) menurut Parasuraman dalam adalah bukti fisik, keandalan, daya tanggap, jaminan dan empati. Empati merupakan respon afektif yang berasal dari pemahaman kondisi emosional orang lain, perasaan yang sama dengan apa yang dirasakan orang lain (Price \& Wilson, 2012). Empati memiliki peran penting pada perkembangan pemahaman sosial dan perilaku social positif dan berfungsi sebagai fondasi suatu hubungan (Nursalam, 2016; Pribadi, Karyanto, \& Yansuri, 2019)

Empati perawat yang ditunjukkan dengan menunjukkan sikap yang sopan dan ramah, mau mendengarkan dan memahami pasiennya akan menciptakan hubungan yang baik antara perawat dan juga pasien serta keluarganya. Hal ini akan membuat pasien merasa lebih nyaman selama mendapatkan pelayanan kesehatan dan akan merasa lebih puas dengan pelayanan yang diberikan. Pelayanan di UPT Puskesmas Rawat
Inap Sragi masih belum sesuai dengan keinginan masyarakat karena masih seringnya terdengar keluhan pasien maupun keluarganya dimana masih seringnya pegawai Puskesmas yang lambat dalam memberikan pelayanan, pasien sering menunggu lama untuk mendapatkan giliran dilayani oleh pegawai. Petugas dalam memberikan pelayanan tidak menunjukkan rasa empati terhadap pasien. Tahun 2015 di Puskesmas Sragi sebanyak 23 penderita TB, di tahun 2016 meningkat menjadi 29 penderita TB paru dan di Tahun 2017 Puskesmas Sragi kembali mengalami peningkatan penderita TB paru menjadi sebanyak 38 orang dengan CDR urutan kedua terendah di Kabupaten Lampung Selatan. Berdasarkan hasil pra survey yang dilakukan pada tanggal 24 Desember 2018 - 2 Januari 2019, dari 5 orang penderita TB di UPT Puskesmas Rawat Inap Sragi Kabupaten Lampung Selatan diketahui bahwa 3 $(60 \%)$ orang tidak patuh dalam pengobatan TB yang dilihat dari kunjungan / kartu TB yang ada, kunjungan yang dilakukan tidak sesuai dengan jadwal yang telah di tentukan dan adanya sisa obat yang seharusnya sudah dihabiskan oleh pasien.

Hal ini didukung oleh hasil wawancara dari ke-3 penderita tersebut dimana terungkap alasan tidak berobat secara teratur karena sudah tidak batuk sehingga menganggap penyakitnya sudah sembuh, selain itu sebagian penderita mengatakan petugas kesehatan kurang ramah saat memberikan penjelasan, terkadang petugas ketika memberikan informasi tidak jelas sehingga pasien merasa bahwa jika sudah tidak merasa sakit maka tidak mengkonsumsi obat karena petugas tidak menjelaskan secara jelas manfaat dari konsumsi obat secara teratur, selain itu penderita mengungkapkan pernah ketika akan berobat petugas tidak sedang di tempat sehingga seharusnya bisa mendapatkan obat di saat itu, tertunda karena petugas tidak ada di tempat dan untuk kembali lagi mengambil obat terkadang terbentur dengan pekerjaan sehingga keluarga tidak dapat menemani pasien untuk mengambil obat.

Dari 5 orang, sebanyak $4(80 \%)$ pasien mengungkapkan bahwa sikap petugas yang tidak segera melayani saat pasien datang sehingga terkadang menjadi pertimbangan pasien untuk datang ke Puskesmas mengambil obat, petugas terkesan kurang ramah dalam melayani pasien dan buru-buru saat melakukan pemeriksaan serta

Muhammad Arifki Zainaro1 Program Studi Diploma III Keperawatan Malahayati Bandar Lampung.

Email: m.arifkiz@yahoo.com

Ahmad Gunawan ${ }^{2 *}$ UPT Puskesmas Rawat Inap Sragi Kabupaten Lampung Selatan.

*Email: ahmadgunawan1965@gmail.com 
memberikan informasinya kurang jelas. Dari 5 pasien, sebanyak 4 (80\%) pasien mengungkapkan bahwa petugas kurang memberikan perhatian dan memberi dukungan moril terhadap keadaan pasien seperti tidak menanyakan dan berbincang-bincang tentang keadaan pasien selama dalam pengobatan, perkembangan yang terjadi dengan pasien juga tidak diungkapkan dengan jelas oleh perawat. Dari keluhan-keluhan tersebut dapat digolongkan dalam aspek-aspek kualitas pelayanan tentang empati.

\section{METODE PENELITIAN}

Penelitian kuantitatif, dengan jenis penelitian cross sectional dengan populasi dalam seluruh penderita TB paru, pengambilan sampel secara purposive dan dilakukan di UPT Puskesmas Rawat Inap Sragi Kabupaten Lampung Selatan, pada tanggal 23 Maret - 25 Juli 2019. Variabel yang diambil adalah mutu pelayanan kesehatan (empati petugas kesehatan) dan kepatuhan minum obat penderita tuberculosis paru, pengambilan data menggunakan kuesioner yang dibagikan ke responden.

HASIL

Tabel 1. Distribusi Frekuensi Kepatuhan Minum Obat $\mathrm{N}=49$

\begin{tabular}{lccc}
\hline Variabel & Kategori & Frekuensi (f) & Persentase (\%) \\
\hline Kepatuhan minum & Patuh & 22 & 44,9 \\
obat TB Paru & Tidak Patuh & 27 & 55,1 \\
\multicolumn{1}{c}{ Total } & & 49 & 100,0 \\
\hline
\end{tabular}

Berdasarkan Tabeldari 49 responden terlihat bahwa sebanyak 22 (44,9\%) responden patuh dan sebanyak 27 $(55,1 \%)$ responden tidak patuh.

Tabel 2. Distribusi Frekuensi Empati Petugas Kesehatan N = 49

\begin{tabular}{lccc}
\hline Variabel & Kategori & Frekuensi (f) & Persentase (\%) \\
\hline Empati Petugas & Baik & 29 & 59,2 \\
& Tidak Baik & 20 & 40,8 \\
Total & & 49 & 100,0 \\
\hline
\end{tabular}

Berdasarkan Tabeldari 49 responden terlihat bahwa sebanyak 29 (59,2\%) responden memiliki empati baik dan sebanyak $20(40,8 \%)$ responden memiliki empati tidak baik.

Tabel 3. Hubungan Antara Empati Petugas Kesehatan Terhadap Kepatuhan Minum Obat N =49

\begin{tabular}{|c|c|c|c|c|c|c|c|c|}
\hline \multirow{3}{*}{ Empati Petugas } & \multicolumn{4}{|c|}{ Kepatuhan Minum Obat } & & & \multirow{3}{*}{$p$-value } & \multirow{3}{*}{$\begin{array}{c}\text { OR } \\
95 \% \mathrm{Cl}\end{array}$} \\
\hline & \multicolumn{2}{|c|}{ Patuh } & \multicolumn{2}{|c|}{ Tidak Patuh } & \multicolumn{2}{|c|}{ Total } & & \\
\hline & $n$ & $\%$ & $\mathbf{n}$ & $\%$ & $\mathbf{N}$ & $\%$ & & \\
\hline Baik & 18 & 62,1 & 11 & 37,9 & 29 & 100,0 & & 6,545 \\
\hline Tidak Baik & 4 & 20,0 & 16 & 80,0 & 20 & 100,0 & 0,009 & $(1,735-$ \\
\hline Total & 22 & 44,9 & 27 & 55,1 & 49 & 100,0 & & $24,965)$ \\
\hline
\end{tabular}

Muhammad Arifki Zainaro1 Program Studi Diploma III Keperawatan Malahayati Bandar Lampung.

Email: m.arifkiz@yahoo.com

Ahmad Gunawan ${ }^{2 *}$ UPT Puskesmas Rawat Inap Sragi Kabupaten Lampung Selatan.

*Email: ahmadgunawan1965@gmail.com 
Berdasarkan tabel diketahui bahwa dari 29 responden dengan empati baik terdapat18 $(62,1 \%)$ responden yang patuh minum obat, dan terdapat $11(37,9 \%)$ responden yang tidak patuh minum

Hasil uji statistik diperoleh $p$-value $=0,009$ yang berarti $p<a=0,05$, maka dapat disimpulkan bahwa ada hubungan antara empati petugas kesehatan dengan kepatuhan minum obat tuberculosis paru, dengan nilai OR 6,545 , artinya responden dengan

persepsi bahwa empati petugas baik memiliki peluang sebesar 6,5 kali akan patuh minum obat jika dibandingkan dengan responden yang merasa bahwa empati petugas kurang baik.

\section{PEMBAHASAN}

\section{Kepatuhan Minum Obat}

Hasil Penelitian dari 49 responden terlihat bahwa sebanyak $22(44,9 \%)$ responden patuh dan sebanyak $27(55,1 \%)$ responden tidak patuh. Sejalan dengan teori kepatuhan menurut Niven (2013) dimana patuh merupakan disiplin dan taat. Sacket dalam mendefinisikan kepatuhan pasien sebagai sejauh mana perilaku pasien sesuai dengan ketentuan yang diberikan oleh petugas kesehatan. Ketidakpatuhan terhadap pengobatan akan mengakibatkan tingginya angka kegagalan pengobatan penderita TB paru, sehingga akan meningkatkan resiko kesakitan, kematian, dan menyebabkan semakin banyak ditemukan penderita TB paru dengan Basil Tahan Asam (BTA) yang resisten dengan pengobatan standar (Niven, 2013) . Pasien yang resisten tersebut akan menjadi sumber penularan kuman yang resisten di masyarakat. Hal ini tentunya akan mempersulit pemberantasan penyakit TB paru di Indonesia serta memperberat pemerintah (Prameswari, 2016).

Kepatuhan dalam pengobatan dapat diartikan sebagai perilaku klien yang mentaati semua nasehat dan petunjuk yang dianjurkan oleh kalangan tenaga. Secara umum, ketidakpatuhan terhadap program terapeutik adalah masalah substansial yang harus diatasi untuk membantu individu berpartisipasi dalam perawatan diri dan mencapai tingkat kesehatan potensial yang maksimal (Ketidakpatuhan minum obat dapat meningkatkan resiko berkembangnya masalah kesehatan atau memperpanjang dan memperburuk kesakitan yang diderita. medis (Iswanti, 2012)

Dari hasil penelitian diketahui sebagian responden patuh minum obat, yaitu sebanyak 22 obat. Dari 20 responden yang tidak empati terdapat $4(20,0 \%)$ responden yang patuh minum obat, dan terdapat $16(80,0 \%)$ responden yang tidak patuh minum obat.

$(44,9 \%)$ responden menurut pendapat peneliti hal ini karena banyak pasien yang tidak ceroboh untuk mengkonsumsi minum obat, banyak pasien yang tidak lupa untuk minum obat, walaupun pasien merasa kesehatannya lebih baik namun tentang mengkonsumsi obat dan responden pun merasa setelah mengkonsumsi obat merasa bahwa badan lebih sehat karena bias berfikir lebih jernih tidak hanya memikirkan penyakit yang di deritanya karena dengan mengkonsumsi obat, responden lebih nyaman namun sebagian responden tidak patuh minum obat, yaitu sebanyak $27(55,1 \%)$ responden, dimana responden ada yang mengungkapkan bahwa ketika mengkonsumsi obat membuat lelah dan lesu selain itu marasa seperti robot karena harus mengkonsumsi obat-obatan sesuia jadwal dan terus menerus dari hal ini dapat disimpulkan bahwa responden merasa bosan dengan mengkonsumsi obat, sehingga terkadang tidak mematuhi jadwal konsumsi obat yang dianjurkan dari petugas kesehatan. Menurut pendapat peneliti kepatuhan minum obat pada penderita TB Paru dipengaruhi oleh dua hal yakni dari dalam diri penderita TB Paru itu sendiri dengan adanya dorongan, keinginan untuk berobat atau melakukan sesuatu yang lebih baik dan dukungan dari keluarga, masyarakat maupun petugas kesehatn dalam menangani kasus penyakit TB Paru tersebut melalui pendidikan kesehatan, memberi support, dorongan sesuai dengan tujuan yang diharapkan.

\section{Empati Petugas Kesehatan}

Hasil Penelitian dari 49 responden terlihat bahwa sebanyak $29(59,2 \%)$ responden memiliki empati baik dan sebanyak $20(40,8 \%)$ responden memiliki empati tidak baik.

Penelitian ini sejalan dengan teori yang dikemukakan empati yaitu membina pengaruh dan perhatian secara individual yang diberikan perusahaan kepada pelanggan seperti mendengarkan keluhan konsumen, kemudahan konsumen untuk menghubungi perusahaan, kemampuan petugas kesehatan untuk berkomunikasi dengan konsumen/pelanggan (Nursalam, 2016). 
Hasil penelitian ini sejalan dengan penelitian yang telah dilakukanHasil penelitian menunjukkan empati kurang baik sebesar $63,5 \%$ dan empati baik sebesar 36,5\% (Manimaran, Sindhya, \& Venkateshwaran, 2010).

Sejalan dengan teori Nursalam (2016) faktorfaktor yang berhubungan dengan empati yaitu sosialisasi, perkembangan kognitif, mood and feeling, situasi dan komunikasi. Menurut pendapat peneliti sikap petugas kesehatan yang kurang ramah dalam memberikan pelayanan kemungkinan disebabkan karena jumlah petugas kesehatan kurang sehingga beban kerja dirasakan cukup berat serta kurangnya motivasi dalam bekerja. Hal ini dapat diatasi dengan cara menambah petugas kesehatan jika memungkinkan untuk merekrut petugas kesehatan baru, tapi jika tidak mungkin bisa dengan cara memberdayakan petugas kesehatan yang ada dengan memberikan uang overtime atau insentif bagi mereka yang memiliki beban kerja yang cukup berat dari petugas kesehatan yang lain maka mereka akan tetap termotivasi bekerja lebih giat dan tanpa mengurangi sifat empati dan keramahan mereka kepada para pelanggan.

\section{Hubungan Empati Petugas Kesehatan Dengan Kepatuhan Minum Obat}

Berdasarkan hasil penelitian diperoleh $p$-value $=0,009$ yang berarti $p<a=0,05$, maka dapat disimpulkan bahwa ada hubungan antara empati petugas kesehatan dengan kepatuhan minum obat tuberculosis paru, dengan nilai OR 6,545, artinya responden dengan persepsi bahwa empati petugas baik memiliki peluang sebesar 6,5 kali akan patuh minum obat jika dibandingkan dengan responden yang merasa bahwa empati petugas kurang baik

Penelitian ini sejalan dengan teori yang dikemukakan oleh Nursalam (2016) empati yaitu membina hubungan dan perhatian secara individual yang diberikan perusahaan kepada pelanggan seperti mendengarkan keluhan konsumen, kemudahan konsumen untuk menghubungi perusahaan, kemampuan perawat untuk berkomunikasi dengan konsumen/pelanggan dan usaha perusahaan untuk memahami kebutuhan pelanggannya. Empati dalam suatu pelayanan adalah adanya suatu perhatian, keseriusan, simpatik, pengertian dan keterlibatan pihak-pihak yang berkepentingan dengan pelayanan untuk mengembangkan dan melakukan aktivitas pelayanan sesuai dengan tingkat pengertian dan pemahaman dari masing-masing pihak tersebut. Pihak yang memberi pelayanan harus memiliki empati memahami masalah dari pihak yang ingin dilayani. Pihak yang dilayani seyogyanya memahami keterbatasan dan kemampuan orang yang melayani, sehingga keterpaduan antara pihak yang melayani dan mendapat pelayanan memiliki perasaan yang sama.Dimensi Empati (empathy) artinya, memberikan perhatian yang tulus kepada pasien yang bersifat individual atau pribadi yang berupaya dalam memahami keinginan pasien (Asmuji, 2014). Persepsi empati merupakan bagian dari dimensi Empati dengan metode SERVEQUAL (Service Quality) yang dikembangkan oleh Parasuraman, yang meliputi kemudahan untuk menghubungi, kemampuan karyawan untuk berkomunikasi dengan pelanggan dan usaha perusahaan untuk memahami kebutuhan pelanggannya. Empati merupakan pelayanan yang diharapkan pasien yang meliputi hubungan perawat - pasien terjaga dengan baik hal ini sangat penting karena dapat membantu dalam keberhasilan penyembuhan dan peningkatan kesehatan pasien. Empati perawat yang ditunjukkan dengan menunjukkan sikap yang sopan dan ramah, mau mendengarkan dan memahami pasiennya akan menciptakan hubungan yang baik antara perawat dan juga pasien serta keluarganya. Hal ini akan membuat pasien merasa lebih nyaman selama mendapatkan pelayanan kesehatan dan akan merasa lebih puas dengan pelayanan yang diberikan.

Hasil penelitian juga menyimpulkan bahwa kualitas pelayanan dan kepuasan berpengaruh positif terhadap loyalitas pasien Rawat Jalan dan Rawat Inap Rumah Sakit Otorita Batam Puti (2013). Penelitian dengan judul hubungan antara persepsi mutu pelayanan asuhan keperawatan dengan kepuasan pasien rawat inap kelas III di RSUD Wangaya Kota Denpasar. Metode: Penelitian ini adalah penelitian kuantitatif dengan menggunakan rancangan potong lintang. Besar sampel 111 orang yang diambil dengan teknik simple random sampling. Data dianalisis secara bertahap meliputi analisis univariat, bivariat dan multivariat dengan regresi logistik. Hasil: Hasil penelitian menunjukkan tingkat kepuasan sebesar $45 \%$. Persepsi daya tanggap dengan $\mathrm{OR}=2,404$ (95\%Cl: 1,076-5,373) dan empati dengan

Muhammad Arifki Zainaro ${ }^{1}$ Program Studi Diploma III Keperawatan Malahayati Bandar Lampung.

Email: m.arifkiz@yahoo.com

Ahmad Gunawan ${ }^{2 *}$ UPT Puskesmas Rawat Inap Sragi Kabupaten Lampung Selatan.

*Email: ahmadgunawan1965@gmail.com 
$\mathrm{OR}=2,594 \quad(95 \% \mathrm{Cl}: \quad 1,165-5,779)$ mempunyai hubungan yang signifikan dengan kepuasan pasien (Wira, 2014)

Berdasarkan hasil penelitian diketahui terdapat responden yang mengungkapkan bahwa empati petugas baik dan patuh minum obat, menurut pendapat peneliti pada penelitian ini menunjukkan bahwa empati perawat dalam meluangkan waktu khusus untuk berkomunikasi dengan pasien dan menghibur serta memberikan dorongan kepada pasien supaya cepat sembuh dan mendoakan mereka masih perlu ditingkatkan, Konsep yang mendasari hubungan perawat pasien adalah hubungan saling percaya, empati, dan caring. Ketidakpuasan pasien sering dikemukakan terhadap sikap dan perilaku perawat Puskesmas serta perawat kurang komunikatif dan informatif dengan pasien. Namun terdapat responden yang tidak patuh minum obat hal ini dapat dikarenakan responden merasa bahwa rutinitas meminum Obat-obatan membuat saudara merasa lelah dan jenuh sehingga responden tidak menelan obat secara rutin setiap hari sesuai petunjuk petugas kesehatan.

Pada penelitian ini responden yang mengungkapkan bahwa petugas tidak empati namun patuh minum obat, dan terdapat responden yang tidak patuh minum obat. Sejalan dengan teori Niven (2013) selain empati dari petugas kesehatan, dukungan keluarga dapat menjadi faktor yang sangat mempengaruhi dalam menentukan keyakinan dan dapat mengobservasi terkait konsumsi obat harian pada penderita paru. Menurut pendapat peneliti perawat memberi dukungan untuk kesembuhan penyakit, menganjurkan berdoa, melakukan komunikasi yang baik dan sopan memiliki point rendah. Seringkali dalam pelayanan, jika pasien tidak menanyakanpenyakit yang dideritanya, maka perawat tidak memberikan penjelasantentang penyakit yang diderita, sehingga antara pasien dengan perawat belum terjadi komunikasi yang baik dan menimbulkan kesan bahwa perawat kurang ramah, kurang perhatian, serta waktu yang diberikan dalam pelayanan sangatsingkat. Terdapat responden yang tidak puas hal ini dikarenakan diketahui bahwa hasil jawaban responden pada pernyataan perawat mudah ditemui dan dihubungi bila anda membutuhkan dan perawat melakukan komunikasi yang baik dan sopan memiliki nilai point rendah.

\section{SIMPULAN}

Diketahui bahwa sebanyak 49 responden terlihat bahwa sebanyak $29(59,2 \%)$ responden memiliki empati baik dan sebanyak $20(40,8 \%)$ responden memiliki empati tidak baik. Diketahui bahwa sebanyak 49 responden terlihat bahwa sebanyak 29 $(59,2 \%)$ responden memiliki empati baik dan sebanyak $20(40,8 \%)$ responden memiliki empati tidak baik Ada hubungan antara empati petugas kesehatan terhadap kepatuhan minum obat tuberculosis paru ( $p$-value=0,009 dan OR 6,545).

\section{SARAN}

Diharapkan peneliti selanjutnya untuk meneliti faktor lain yang mempengaruhi tingkat kepatuhan minum obat dan penggunaan desain penelitian yang berbeda, misalnya desain penelitian kohort. Selain itu, peneliti selanjutnya dapat melakukan penelitian terapan berupa intervensi kesehatan untuk meningkat kepatuhan minum obat pasien tuberkulosis paru.

\section{DAFTAR PUSTAKA}

Asmuji. (2014). Manajemen Keperawatan: Konsep dan Aplikasi. Ar-. Ruzz Media: Yogyakarta

Dinas Kesehatan Lampung Selatan (2017). Profil Kesehatan Provinsi Lampung Selatan Tahun 2016. Lampung.

Dinas Kesehatan Provinsi Lampung. (2017). Profil Kesehatan Provinsi Lampung Tahun 2016. Lampung.

Finn, R. S., Martin, M., Rugo, H. S., Jones, S., Im, S. A., Gelmon, K., \& Gauthier, E. (2016). Palbociclib and letrozole in advanced breast cancer. New England Journal of Medicine, 375(20), 19251936.

Iswanti. D. I. (2012). Pengaruh Terapi Perilaku Modeling Partisipan Terhadap Kepatuhan Minum Obat Pada Klien Penatalaksanaan Regimen Terapeutik Tidak Efektif di RSJD Dr. Amino Gondohutama Semarang. Universitas Indonesia. Available at: http://lib. ui. ac. id/opac/ui/detail. jsp.

Kementerian Kesehatan Republik Indonesia. (2016). Panduan Peringatan Tb Seduania 2015. Jakarta.

Muhammad Arifki Zainaro1 Program Studi Diploma III Keperawatan Malahayati Bandar Lampung.

Email: m.arifkiz@yahoo.com

Ahmad Gunawan 2* UPT Puskesmas Rawat Inap Sragi Kabupaten Lampung Selatan.

*Email: ahmadgunawan1965@gmail.com 
Kementerian Kesehatan Republik Indonesia. (2017). Profil Kesehatan Indonesia Tahun 2016. Jakarta.

Kementerian Kesehatan Republik Indonesia. (2017). Profil Kesehatan Indonesia Tahun 2016. Jakarta

Kementrian Kesehatan Republik Indonesia (2016). InfoDATIN: Situasi Balita Pendek. Jakarta: Pusat Data dan Informasi.

Manimaran, S., Sindhya, R., \& Venkateshwaran, P. S. (2010). A study of patients expectation and satisfaction in dindigul hospitals. Asian Journal of Management Research, 1(1), 31-43.

Niven, N. (2013). Psikologi Kesehatan Dan IImu Perilaku.Jakarta: EGC.

Notoatmodjo. S. (2014). Promosi Kesehatan dan IImu Perilaku. Jakarta: Rineka. Cipta

Nursalam, N. (2016). Manajemen keperawatan: Aplikasi dalam praktek keperawatan profesional. Jakarta: Salemba Medika.

Nursalam, N. (2016). Manajemen keperawatan: Aplikasi dalam praktek keperawatan profesional. Jakarta: Salemba Medika

Nursini, R. (2010). Analisis pengaruh kualitas pelayanan terhadap kepuasan pasien rawat jalan di Puskesmas Teras Boyolali Tahun 2010 (Doctoral dissertation, Universitas Muhammadiyah Surakarta).

Pohan. I. S. (2017). Jaminan Mutu Layanan Kesehatan: Dasar-Dasar Pengertian Dan Penerapan. Jakarta: EGC.

Prameswari, C. (2016). Mengasuh anak dengan hati. Saufa.
Pribadi, T. (2017). Hubungan kinerja perawat dalam tindakan keperawatan dengan kepuasan pasien di ruang rawat inap penyakit dalam. Holistik Jurnal Kesehatan, 11(1), 59-65.

Pribadi, T., Karyanto, K., \& Yansuri, Y. (2019). Hubungan gambaran diri dalam berinteraksi sosial pada penderita TB paru di wilayah kerja UPT Puskesmas Negeri Agung LampungIndonesia. Holistik Jurnal Kesehatan, 13(2), 184-193.

Price, S. A., \& Wilson, L. M. (2012). Patofisiologi konsep klinis proses-proses penyakit. Jakarta: EGC.

Puti, W. C. (2013). Pengaruh Kualitas Pelayanan Dan Kepuasan Terhadap Loyalitas Pasien Rawat Jalan Dan Rawat Inap Rumah Sakit Otorita Batam.

Subhakti, K. A. (2014). Hubungan dukungan keluarga dengan tindakan penderita TB paru melakukan kontrol ulang di Puskesmas Sidomulyo. Jurnal Online Mahasiswa Program Studi IImu Keperawatan Universitas Riau, 1(1), 1-6.

Tjiptono. F. (2015). Strategi Pemasaran (Edisi Keempat). Yogyakarta: CV Andi Offset.

Wira. I. A. D. (2014). Hubungan antara persepsi mutu pelayanan asuhan keperawatan dengan kepuasan pasien rawat inap kelas III Di RSUD Wangaya Kota Denpasar. Universitas Udayana.

World Health Organization. (2017). Global tuberculosis report 2013. World Health Organization.

Muhammad Arifki Zainaro ${ }^{1}$ Program Studi Diploma III Keperawatan Malahayati Bandar Lampung. 